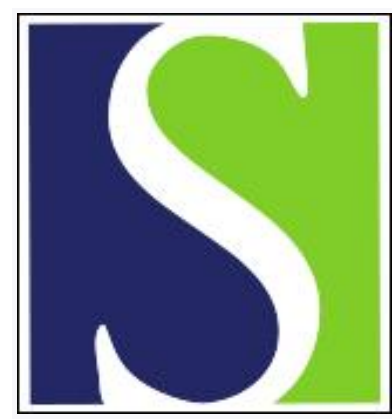

Scand J Work Environ Health 1976;2(3):176-184

https://doi.org/10.5271/sjweh.2812

Issue date: Sep 1976

Effect of a short, heavy exposure to lead dust upon blood lead level, erythrocyte delta-aminolevulinic acid dehydratase activity and urinary excretion of lead delta-aminolevulinic acid coproporphyrin. Results of a 6-month follow-up of two male subjects.

by Schütz A, Skerfving S

Key terms: blood; blood lead; blood lead level; coproporphyrin; dehydratase activity; delta-aminolevulinic acid; delta-aminolevulinic acid coproporphyrin; delta-aminolevulinic acid dehydratase activity; erythrocyte; excretion; experimental exposure; exposure; follow up; half-time; heavy exposure; lead; lead dust; male subject; man; short exposure; urinary excretion; urine

This article in PubMed: www.ncbi.nlm.nih.gov/pubmed/788149 


\title{
Effect of a short, heavy exposure to lead dust upon blood lead level, erythrocyte $\delta$-aminolevulinic acid dehydratase activity and urinary excretion of lead, $\delta$-aminolevulinic acid and coproporphyrin
}

\section{Results of a 6-month follow-up of two male subjects $^{1}$}

by ANDREJS SCHÜTZ, B.Sc., and STAFFAN SKERFVING, M.D.²

\begin{abstract}
SCHÜTZ, A. and SKERFVING, S. Effect of a short heavy exposure to lead dust upon blood lead level, erythrocyte $\delta$-aminolevulinic acid dehydratase activity and urinary excretion of lead, $\delta$-aminolevulinic acid and coproporphyrin: Results of a 6-month follow-up of two male subjects. Scand. $j$. work environ. \& health 3 (1976) 176-184. During $1 \mathrm{~h}$ two healthy volunteers, not earlier exposed occupationally to lead, inhaled about $100 \mathrm{mg}$ of lead as a mixture of lead oxides and lead sulfate. Maximum blood lead $(\mathrm{PbB})$ concentrations of about $0.5 \mathrm{mg} / 1$ and minimum blood cell $\delta$-aminolevulinic acid dehydratase activities (ALAD) (6\% of the preexposure values) were observed within $38 \mathrm{~h}$ after exposure. $\mathrm{PbB}$ and $\mathrm{ALAD}$ returned to preexposure levels after about 300 and 150 days. A highly significant correlation between ALAD and $\mathrm{PbB}$ was seen even at lead levels in the range $0.1-0.2 \mathrm{mg} / \mathrm{l}$. Delta-aminolevulinic acid, coproporphyrin and lead in the urine (ALAU, CPU, and $\mathrm{PbU}$, respectively) increased. The peak levels occurred after about $15 \mathrm{~h}$ for ALAU and CPU and after about $24 \mathrm{~h}$ for $\mathrm{PbU}$. There was a very good correlation between $\log \mathrm{PbU}$ and $\operatorname{lin}$ $\mathrm{PbB}$. ALAU increased already at $\mathrm{PbB}$ levels of about $0.3 \mathrm{mg} / \mathrm{l}$.
\end{abstract}

Key words: lead, experimental exposure, excretion, blood, urine, $\delta$-aminolevulinic acid, $\delta$-aminolevulinic acid dehydratase, coproporphyrin, half-time.

Workers under surveillance because of lead $\mathrm{Pb}$ ) exposure sometimes show unexpected, temporary rises in their blood lead $(\mathrm{PbB})$ levels. A possible explanation could

1 Partly presented at the XVIII International Congress on Occupational Health, Brighton, England, 14-19 September 1975.

2 Department of Occupational Medicine, University Hospital, Lund, Sweden.

Reprint requests to: Mr. Andrejs Schütz, Department of Occupational Medicine, University Hospital, S-221 85 Lund, Sweden. be the occurrence of a short, but intensive, exposure in addition to continuous occupational exposure and "background" nonoccupational exposure. In blood samples obtained from workers before and after 8-h workdays in workroom levels of 0.2 $\mathrm{mg} \mathrm{Pb} / \mathrm{m}^{3}$ or less, we found no significant $\mathrm{PbB}$ rise. Thus we conducted an experiment in which persons formerly exposed only to nonoccupational "background" lead were subjected to lead levels higher than $0.2 \mathrm{mg}$ $\mathrm{Pb} / \mathrm{m}^{3}$. Such an experiment also provided the opportunity to study lead metabolism, 
information on which is scanty in several aspects $(7,9,31,36)$. It should also supply intraindividual data from humans on the relationship between lead levels in blood and urine on one hand and different biochemical parameters on the other. This relationship has usually been studied only in exposed groups, and interindividual variation has affected the results.

\section{MATERIAL AND METHODS}

\section{Subjects}

Two male volunteers 33 and 37 years of age participated in the investigation. They had no earlier occupational exposure to lead. Subject 1 was a smoker (about 10 cigarettes/day) and subject 2 a nonsmoker. Their weights were 78 and $80 \mathrm{~kg}$. Both were healthy. They had normal hemoglobin levels in blood, normal creatinine levels in serum, no glucosuria or albuminuria, a normal ability to concentrate urine, and normal liver function as indicated by serum activities of aminotransferases (S-ALAT and S-ASAT).

\section{Exposure and sampling}

The volunteers were exposed for $60 \mathrm{~min}$ to lead dust (a mixture of lead oxides and lead sulfate) in a closed section of a destruction facility for lead storage batteries. Samples for the determination of lead in air were obtained during exposure, those for the determination of $\mathrm{PbB}$ (whole blood) and $\delta$-aminolevulinic acid dehydratase activity (ALAD; EC 4.2.1.24) in red blood cells (RBC) were obtained on several occasions before exposure and during a period of 500 days after it, and those for the determination of lead, $\delta$-aminolevulinic acid, and coproporphyrins in urine ( $\mathrm{PbU}$, ALAU, and CPU, respectively) were collected during the postexposure period.

Lead in air. We determined individual exposure from dust samples collected on cellulose acetate membrane filters (Millipore; pore diameter $0.8 \mu \mathrm{m}$ ) with a portable pump (MSA model $\mathrm{G} ; 2 \mathrm{l} / \mathrm{min}$ ) in the breathing zones of the subjects. The filters were treated with concentrated nitric acid. After dilution of the samples with de- ionized water, the lead content was determined by atomic absorption spectrophotometry (AAS). The detection limit was $2.5 \mu \mathrm{g}$, which corresponds to an air level of $25 \mu \mathrm{g} / \mathrm{m}^{3}$. The combined method error, including the determination of air sample volume and lead content, was calculated to be $7 \%$. The average lead concentration in the breathing zones of the two subjects (data on subject 1 will always be presented first) was 51 and $54 \mathrm{mg} / \mathrm{m}^{3}$. Lung ventilation, as estimated under the same conditions on a later occasion with the use of Douglas bags, was about 30 $1 / \mathrm{min}$. The inhaled amount of lead was thus calculated to be $90-100 \mathrm{mg}$ for the two subjects.

Particle size of lead dust. Dust for the determination of particle size was sampled on cellulose acetate membrane filters (Millipore; pore size $0.22 \mu \mathrm{m}$ ) and on Nuclepore membrane filters (General Electric; pore size $0.4 \mu \mathrm{m}$ ). The acetate membrane filters were made transparent by treatment with acetone vapor, and the particle size was estimated by bright field microscopy at a magnification of 400 times. The particle size distribution on the Nuclepore filters was determined in photographs taken at a magnification of 1,200 times in a scanning electron microscope. Of the particles $93 \%$ were in the range $0.5-5$ $\mu \mathrm{m}$ (table 1).

Dust samples were also collected with a gravimetric size-selecting personal dust sampler (C. F. Casella \& Co., LTD) (1). During two 30 -min sampling periods 9 and $11 \%(\mathrm{w} / \mathrm{w})$ of the lead passed the cyclone size-selector.

Lead in blood. Venous blood samples were obtained in heparinized acidwashed tubes. On each occasion two to four $5-\mathrm{ml}$ samples of blood were wet-ashed with nitric acid, perchloric acid, and sulfuric acid. The lead was extracted as a dithizone complex in methyl isobutyl ketone and determined by AAS. A satisfactory accuracy was ascertained by repeated interlaboratory checks with independent methods (AAS and spectrography). The limit of detection was $0.01 \mathrm{mg} / \mathrm{l}$, and the method error, as calculated from 20 duplicate determinations in the concentration interval $0.04-0.12 \mathrm{mg} / 1$, was $4 \%$ of the mean. 
Table 1. Particle size distribution for the aerosol of lead oxides and lead sulfate inhaled by the volunteers.

\begin{tabular}{|c|c|c|}
\hline \multirow[b]{2}{*}{$\begin{array}{l}\text { Particle size } \\
(\mu \mathrm{m})\end{array}$} & \multicolumn{2}{|c|}{ Percentage distribution } \\
\hline & $\begin{array}{l}\text { Bright field } \\
\text { microscope } \\
\quad(x 400)\end{array}$ & $\begin{array}{l}\text { Scanning } \\
\text { electron } \\
\text { microscope b } \\
(\mathbf{x} 1,200)\end{array}$ \\
\hline$<\quad 0.5$ & $-\mathrm{c}$ & $-c$ \\
\hline $0.5-1$ & 57 & 25 \\
\hline $1-5$ & 35 & 68 \\
\hline $5-10$ & 6 & 6 \\
\hline $10-15$ & 1 & 1 \\
\hline$>\quad 15$ & $<<1$ & $<1$ \\
\hline Total & $99+$ & $100+$ \\
\hline
\end{tabular}

a A total of 1,090 particles were counted.

b A total of 206 particles were counted.

c Neither method permitted the counting of particles smaller than $0.5 \mu \mathrm{m}$. With scanning electron microscopy using a magnification of $x 6,000$, only a few particles smaller than 0.5 $\mu \mathrm{m}$ were detected.

Lead in urine. During the first 3 days after exposure all urine was taken from each voiding. Later $24-\mathrm{h}$ urine samples were collected during at least three consecutive days. PbU, ALAU, CPU, and creatinine levels were all determined from these samples.

$\mathrm{PbU}$ was determined spectrophotometrically after the lead was precipitated (coprecipitation with calcium from $40 \mathrm{ml}$ of urine added to ammonia), the precipitate was dissolved in diluted hydrochloric acid, and the lead dithizonate was extracted in chloroform after the addition of a citric acid ammonia cyanide buffer $(\mathrm{pH}$ 11-12). The method is a modification of the procedure described by Amdur (2). The main modification involves adding copper sulfate and nitric acid to the sample and heating it to $90^{\circ} \mathrm{C}$ for $1 \mathrm{~h}$ before the precipitation reaction; in this manner lead recovery is increased in different samples from $30-90 \%$ to $100 \%$. Each sample was analyzed twice. The results obtained with this procedure agreed well with those determined with independent AAS (after wet-ashing) and colorimetric methods. The detection limit was about $0.003 \mathrm{mg} / 1$. The method error, as calculated from 20 duplicate analyses in each interval of $0.005-$
$0.020,0.02-0.05,0.05-0.10$, and $0.1-0.2$ $\mathrm{mg} / \mathrm{l}$ was $14,6,4$ and $3 \%$, respectively.

$A L A D$ activity in blood. Determinations of ALAD activity in blood were performed within $1 \mathrm{~h}$ after sampling according to the method of Bonsignore et al. (5) with some modifications (28). The method error, as determined by analyses of duplicate samples within the interval $60-200 \mu \mathrm{mol}$ porphobilinogen (PBG) $\cdot \mathrm{h}^{-1} \cdot 1 \mathrm{RBC}^{-1}$, was $5 \%$ at the low end of the interval and $3 \%$ at the high end. Methylmercury (28) and ethanol (19) causes a decrease in ALAD activity. Both subjects had "normal" mercury levels in their blood cells (below $10 \mu \mathrm{g} / \mathrm{kg}$ ). No intake of alcohol occurred during $24 \mathrm{~h}$ before the sampling.

ALA in urine. Determinations of ALAU were made according to Grabecki et al. (10). They were corrected with regard to the variation in the recovery of ALA in urine samples with different creatinine concentrations with the use of the function $\mathrm{y}=133-21 \times(0.5<\mathrm{x}<2.5 ; \mathrm{n}=10$; $\mathrm{r}=-0.96$ ), where $\mathrm{y}$ denotes recovery in per cent and $x$ the creatinine level in grams per liter. The detection limit was about $1 \mathrm{mg} / \mathrm{l}$. The method error, as calculated from 20 duplicate analyses in the range $5-10 \mathrm{mg} / \mathrm{l}$, was $7 \%$.

Coproporphyrin in urine. The CPU was determined according to Askevold (3). Coproporphyrinogen was oxidized by the method of Schwartz et al. (27). The calculations were made according to Rimington and Sveinsson (24) and With (38). The detection limit was about $0.01 \mathrm{mg} / \mathrm{l}$, and the method error, as calculated from 20 duplicate samples in the range $0.10-$ $0.20 \mathrm{mg} / \mathrm{l}$, was $3 \%$.

Creatinine in urine. Creatinine was determined in all samples according to the method of Teger-Nilsson (32). The method error of 10 consecutive analyses of one sample was $2 \%$.

\section{Calculations of $\mathrm{PbB}$ half-times}

Data on $\mathrm{PbB}$ versus time was fitted to the sum of two exponential functions with the weighted least squares method. The analytical error was assumed to be proportional to the measured values. 

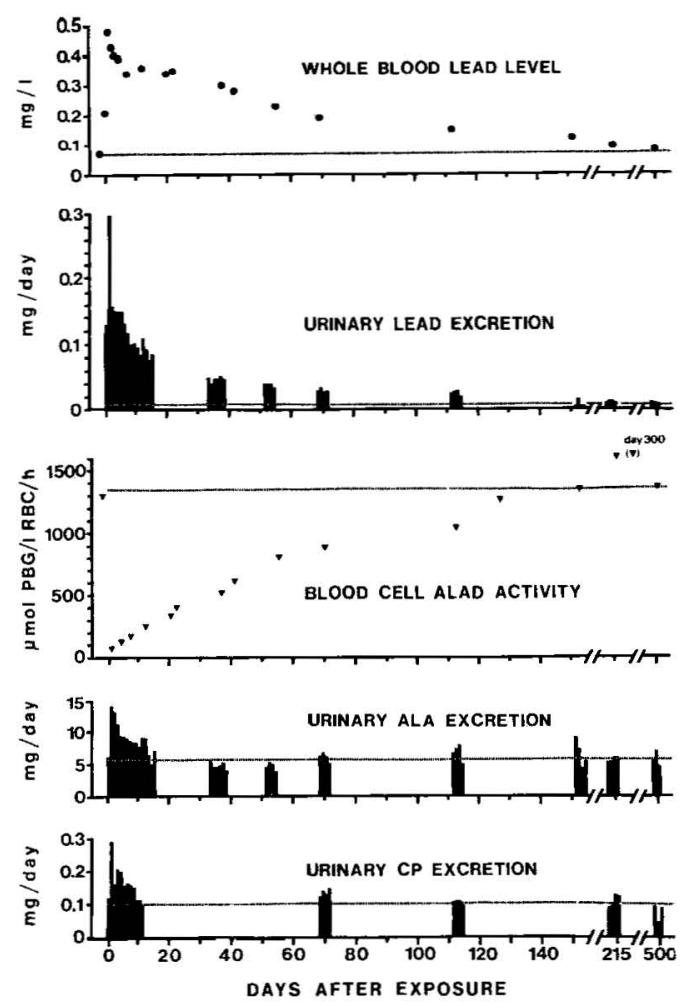

Fig. 1. Levels of lead in whole blood and in urine, $\delta$-aminolevulinic acid dehydratase (ALAD) activity in blood cells, levels of $\delta$ aminolevulinic acid (ALA) and coproporphyrin (CP) in urine before and after a short, heavy inhalation exposure of subject 2 to lead. The dotted lines indicate "background" levels present before exposure and after the end of decay.

\section{RESULTS}

The pattern of $\mathrm{PbB}, \mathrm{PbU}, \mathrm{ALAD}, \mathrm{ALAU}$, and CPU was similar in both subjects. One set of data is presented in fig. 1.

\section{Lead in blood}

Before exposure the $\mathrm{PbB}$ of both subjects was about $0.08 \mathrm{mg} / 1$ (fig. 1). In blood samples obtained about $10 \mathrm{~min}$ after the end of exposure $\mathrm{PbB}$ was 0.16 and 0.21 $\mathrm{mg} / \mathrm{l}$. The next morning, $14 \mathrm{~h}$ after exposure, the highest levels, 0.44 and 0.48 $\mathrm{mg} / \mathrm{l}$, were measured; they were about six times higher than the "background" level.
After an additional $24 \mathrm{~h}$ the levels had decreased to 0.37 and $0.43 \mathrm{mg} / \mathrm{l}$, and after about 250 and 300 days they had returned to levels practically identical with the preexposure ones.

The decrease in $\mathrm{PbB}$ was initially very rapid, but slower later on (fig. 2). When the decay curves were fitted to the sum of two exponential functions, the fast ones had half-times of 1.3 and 0.5 (95 \% confidence limits $0.7-5$ and $0.2-\infty$ ) days, and the slow ones half-times of 46 and 49 (confidence limits $41-52$ and $45-54$ ) days.

\section{Lead in urine}

$\mathrm{PbU}$ rapidly increased to peak levels that were about 50 times higher than the "background" levels (17 and $19 \mu \mathrm{g} / \mathrm{h}$; 240 and $210 \mu \mathrm{g} / \mathrm{g}$ creatinine) in samples voided about $24 \mathrm{~h}$ after exposure, and a slow decrease followed, the "backround" level being reached approximately 150 days later.

The total amount of lead in the urine in excess of the "background excretion" was

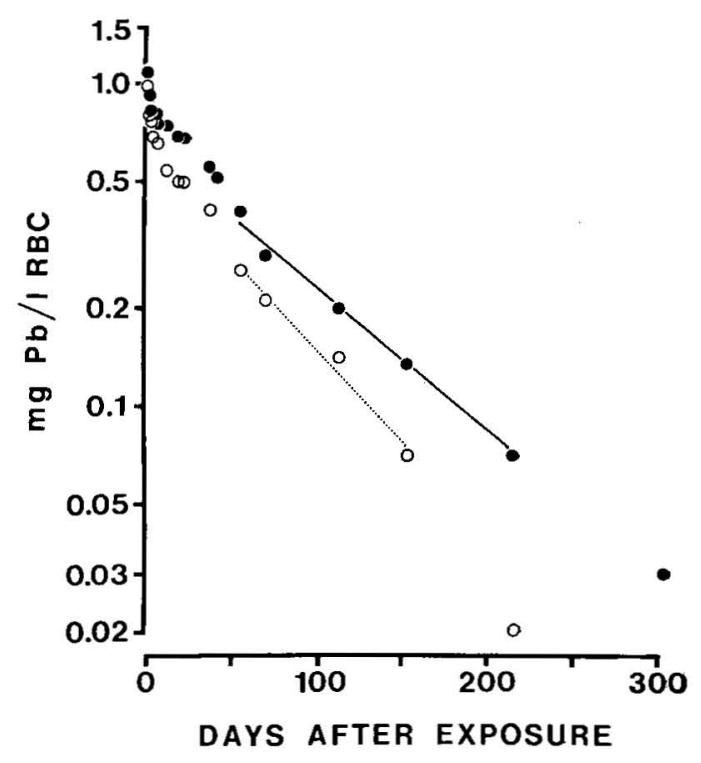

Fig. 2. Levels of lead in red blood cells (RBC) after a short, heavy inhalation exposure of subjects 1 (circles) and 2 (dots) to lead. "Background" levels have been subtracted and logarithms of the differences plotted. 


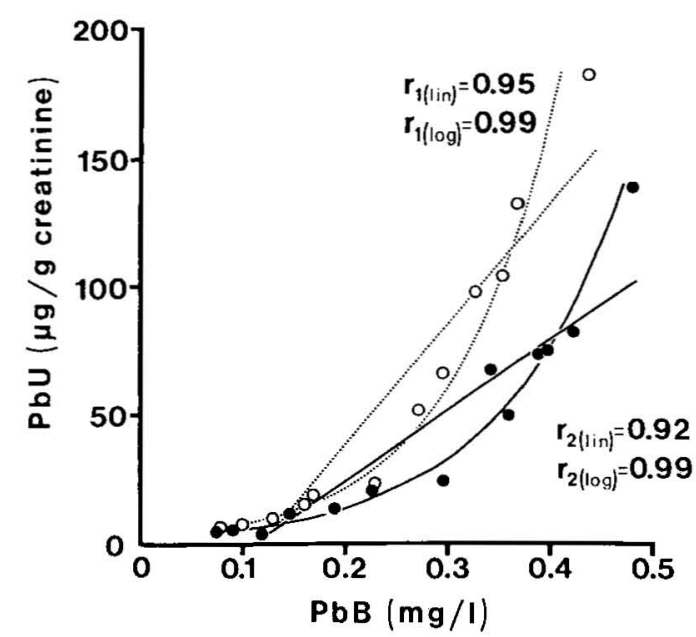

Fig. 3. Relation between levels of lead in whole blood $(\mathrm{PbB})$ and the excretion of lead in urine $(\mathrm{PbU})$ at different times after a short, heavy inhalation exposure of subjects 1 (circles) and 2 (dots) to lead. Both linear and exponential regression lines are indicated together with the corresponding coefficients of correlation.

calculated to be about $5 \mathrm{mg}$ from the areas under the decay curves (fig. 1).

There was an obvious correlation between $\mathrm{PbU}$ and $\mathrm{PbB}$ (fig. 3). The data for each subject fitted a single exponential function $\left(r_{1}=r_{2}=0.99\right)$ better than a rectilinear one $\left(r_{1}=0.95\right.$ and $\left.r_{2}=0.92\right)$.

\section{$A L A D$ activity}

The impact of the absorbed lead on ALAD activity was very rapid. The minimum activities - in both subjects $6 \%$ of the preexposure values - were measured in the first samples taken after exposure for ALAD activity analysis, i.e., $14 \mathrm{~h}$ after the end of exposure.

ALAD activity recovered as $\mathrm{PbB}$ decreased, and after 200 to 300 days it even exceeded the preexposure levels in both subjects. In samples analyzed 500 days after exposure the activities had returned to preexposure values.

Excellent intraindividual correlations were found between ALAD activity and lead in the RBC (fig. 4). The data fitted single exponential curves somewhat better than rectilinear ones $\left(r_{1}=r_{2}=-0.97\right.$ for $\log$ ALAD; $r_{1}=-0.95$ and $r_{2}=-0.97$ for lin ALAD). A statistically significant cor- relation $\left(\mathrm{r}_{1}=-0.86, \mathrm{p}<0.02\right.$ and $\mathrm{r}_{2}=$ $-0.92, p<0.01)$ existed already at the $\mathrm{PbB}$ interval of $0.1-0.2 \mathrm{mg} / 1$.

\section{$A L A$ in urine}

ALAU was increased above the "background" level $(0.3$ and $0.2 \mathrm{mg} / \mathrm{h} ; 4$ and 3 $\mathrm{mg} / \mathrm{g}$ creatinine) in subject 1 for about 1 week and in subject 2 for about 2 weeks after exposure. A maximum excretion of three times higher than the "background" ( 0.7 and $0.7 \mathrm{mg} / \mathrm{h} ; 11$ and $9 \mathrm{mg} / \mathrm{g}$ creatinine) occurred in samples voided about $15 \mathrm{~h}$ after exposure, - i.e., simultaneously with the highest $\mathrm{PbB}$ level observed but nearly $10 \mathrm{~h}$ earlier than the maximum excretion of $\mathrm{PbU}$.

A clear increase in ALAU was seen above a $\mathrm{PbB}$ level of $0.3 \mathrm{mg} / \mathrm{l}$ (fig. 5). A statistically significant correlation was obtained for one of the subjects $\left(r_{2}=0.95\right.$, $\mathrm{p}<0.01)$ at $\mathrm{PbB}$ levels above $0.3 \mathrm{mg} / \mathrm{l}$.

\section{Coproporphyrin in urine}

The pattern of coproporphyrin excretion was similar to that of ALA - the maximum excretion occurred about $15 \mathrm{~h}$ after exposure and was about three times higher than the "background."

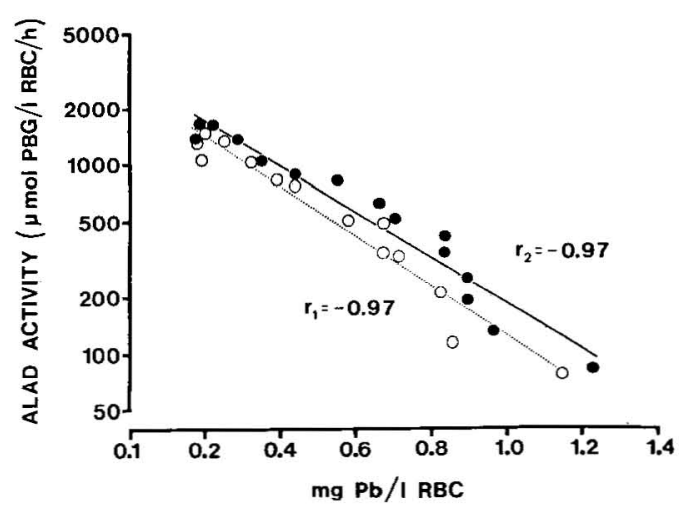

Fig 4. Relation between lead and $\delta$-aminolevulinic acid dehydratase (ALAD) activity in red blood cells (RBC) at different times after a short, heavy inhalation exposure of subjects 1 (circles) and 2 (dots) to lead. Logarithms of ALAD activity have been plotted. 


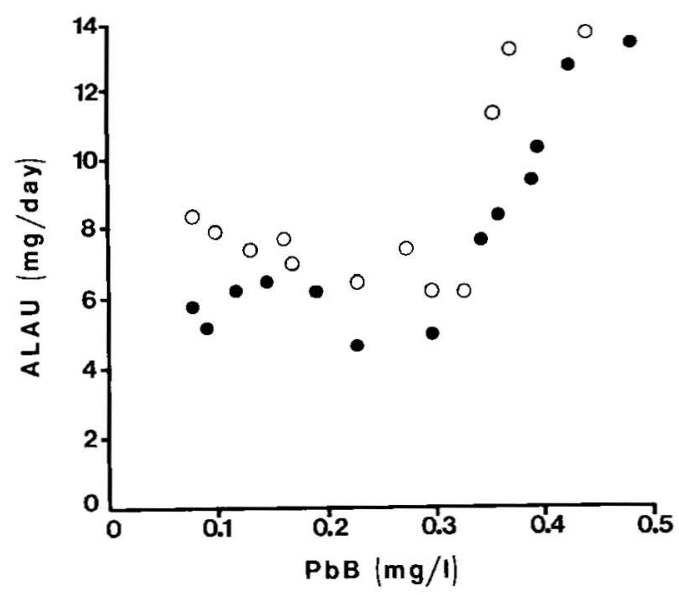

Fig. 5. Relation between levels of lead in whole blood $(\mathrm{PbB})$ and the $24-\mathrm{h}$ excretion of $\delta$-aminolevulinic acid in urine (ALAU) at different times after a short, heavy inhalation exposure of subjects 1 (circles) and 2 (dots) to lead.

\section{DISCUSSION}

The metabolism of lead is complicated. Models containing from two (30) to four (20) compartments have been proposed. Rabinowitz et al. (22) fitted data on one human, subject only to "background" exposure, with a three-compartment model. The first two pools (blood and other soft tissues?) had half-times of about 20 days. The authors also found one compartment (bone?) which had a half-time of 20 years. A very slow decay of the body burden may also be anticipated from $\mathrm{PbB}$ data on "nonexposed" former lead workers $(13,21)$.

One may assume that the decay in $\mathrm{PbB}$ (fig. 2) in the present investigation reflects the excretion kinetics of two compartments with different half-times (blood and soft tissues?). Thus we fitted the curves with the sum of two exponential functions. However, the following three objections may be raised to this assumption: (a) The shape of the initial part of the curve may have been affected by blood absorbing lead from the lungs and the gastrointestinal tract simultaneously as lead was cleared from the blood into other tissues and urine. The rising $\mathrm{PbB}$ levels indicated that an absorption of lead occurred already during the $1-\mathrm{h}$ exposure period. The $\mathrm{PbB}$ started to decline already within $24 \mathrm{~h}$ after the end of exposure; therefore the major part of the absorption was probably completed within that short period. This result agrees with earlier findings (17). (b) Only for subject 1 could the presence of two different functions be firmly established. For subject 2 the range of the $95 \%$ confidence limits of the half-times of the two functions overlapped. (c) The curvilinear relation obtained between $\mathrm{PbU}$ and $\mathrm{PbB}$ indicates that the urinary clearance of lead from whole blood may not follow firstorder kinetics at high $\mathrm{PbB}$ levels, at least in recently exposed subjects. At levels of $0.3 \mathrm{mg} \mathrm{Pb} / 1 \mathrm{RBC}(\mathrm{PbB} 0.14 \mathrm{mg} / \mathrm{l}$, "background" level subtracted) and lower, the decay curves fit well with single exponential functions and the decay rates are remarkably similar for the two subjects. At these levels the relation between $\mathrm{PbU}$ and $\mathrm{PbB}$ is reasonably rectilinear (fig. 3). It may be assumed that this part of the curve mainly reflects clearance from a fairly rapid compartment (soft tissues?).

The estimated total amount of lead inhaled by the volunteers was $90-100 \mathrm{mg}$. It is impossible to make a reliable estimate of the fraction deposited in and absorbed from the lungs. The rest was cleared from the respiratory tract, and most of it was swallowed and partly absorbed from the gastrointestinal tract. An assumption of $5-10 \%$ absorption in the lung (as judged from the fraction passing the particle sizeselector) and 5-10\% of the rest in the intestine (23) would indicate an absorbed dose ranging from 10 to $20 \mathrm{mg}$. About $5 \mathrm{mg}$ of the dose appeared in the urine during the study. Published data on the elimination of lead in feces is not consistent (8), but probably a similar amount or less (23) was excreted through that route. Thus it may be assumed that the dose was not completely eliminated during the study. The rest must have been retained in the body in a slow compartment, mainly in the bone. The lead content of the skeleton is - even in occupationally nonexposed subjects - relatively high $(4,26$, 37) when it is compared to the amount that could possibly have been retained in this study. Thus, when the analytical method 
errors are considered, no significant persistent elevation of $\mathrm{PbB}$ as a result of a small increase of lead in the skeleton should be expected after the lead contents of the rapid compartments have decayed.

The curvilinear relation between $\mathrm{PbU}$ and $\mathrm{PbB}$ has not been reported earlier, but our findings agree with the observations that poisoned subjects may daily excrete considerable amounts of lead in their urine (18). The shape of the curve may be due to (a) absorption of lead from the lungs and the gut and a subsequent relatively higher rise in plasma lead level than in RBC lead level (23) and/or (b) an increasing ratio between lead levels in plasma and blood cells (because of binding conditions) as whole blood levels rise (6); in both cases the renal glomerular filtration rate would be affected. Lead in urine and plasma may very well be linearly related. Also, theoretically, (c) a limited capacity of tubular reabsorption of lead could give a curvilinear relation. However, the limited data on hand (39) indicate a tubular reabsorption at high $\mathrm{PbB}$ levels only.

We found a dramatic decrease in ALAD activity in the $R B C$ already within $14 \mathrm{~h}$ after the short heavy exposure, i.e., earlier by days than the decrease reported in workers at the onset of lead exposure (16, 35). It is reasonable to assume that ALAD activity decreased already during the exposure as $\mathrm{PbB}$ rose. The activity increased as soon as $\mathrm{PbB}$ decreased, i.e., within $24 \mathrm{~h}$ after the end of exposure. A recovery of activity has previously been observed in workers examined 4 months after the end of exposure $(13,33)$.

It is also noteworthy that, in accordance with observations on the relationship between $\mathrm{ALAD}$ and $\mathrm{PbB}$ in lead workers during and after exposure $(13,33)$, ALAD activity even exceeded the preexposure level during one period in our experiment. This result might have been due to a compensatory increase in ALAD (or any other biochemical function which optimizes ALAD activity) in the erythropoetic system and a subsequent enhanced activity in young RBC. Another possibility is the formation of a lead-inactivating compound.

There was an excellent intraindividual correlation between ALAD activity and $\mathrm{PbB}$ in our study, far better than has been reported for groups of individuals $(11,12$, $13,16,25,34)$ for whom interindividual variations influenced the results. There has been some discussion on whether a threshold $\mathrm{PbB}$ exists with regard to impact on ALAD activity. Some authors have claimed an effect already at $\mathrm{PbB}$ levels of $0.1-0.2 \mathrm{mg} / 1(14,15,34)$, while others $(11$, $12,13,25)$ could demonstrate effects only at higher $\mathrm{PbB}$ levels. The present data clearly show an effect at $0.1-0.2 \mathrm{mg} / 1$, i.e., close to levels usually found in "nonexposed" Swedes (12).

A clear increase in ALAU was noted at $\mathrm{PbB}$ levels of $0.3 \mathrm{mg} / \mathrm{l}$, which is lower than the $0.4(29,35)-0.5(12,25,34) \mathrm{mg} / 1 \mathrm{re}-$ ported in studies of groups of workers.

CPU seems to be as sensitive as ALAU in the determination of lead exposure. However, we did not measure the level in all urine specimens, and thus the threshold $\mathrm{PbB}$ resulting in elevated $\mathrm{CPU}$ cannot be given.

It is remarkable that the peaks of ALAU and CPU occurred about $10 \mathrm{~h}$ before the peak $\mathrm{PbU}$. As the time of the peak $\mathrm{PbB}$ is not exactly known, the discrepancy cannot be elucidated. If the peaks of $\mathrm{PbB}, \mathrm{ALAU}$, and CPU occurred simultaneously, the $\mathrm{PbU}$ delay may be due to diurnal variation (18). If, however, the peak $\mathrm{PbB}$ occurred simultaneously with the peak $\mathrm{PbU}, \mathrm{a}$ partial compensatory restitution of heme synthesis (as mentioned previously) might already have occurred.

The short heavy exposure of the volunteers caused a rapid and considerable increase in $\mathrm{PbB}$. Although it must be kept in mind that the present data were obtained from two formerly "occupationally unexposed" subjects after inhalation of a very heavy single dose, it is reasonable to assume that occupationally exposed workers with elevated $\mathrm{PbBs}$ would show a further rise in $\mathrm{PbB}$ after a heavy additional dose. It is, however, not possible to predict the increase since the rise in $\mathrm{PbB}$ might depend upon the lead already present in different body compartments. Because of the apparent curvilinear relation between $\mathrm{PbU}$ and $\mathrm{PbB}$, a rapid elimination of additional lead may be expected and thus a more rapid decrease in $\mathrm{PbB}$ to the level present before the additional exposure may occur. 


\section{ACKNOWLEDGMENT}

The calculations of $\mathrm{PbB}$ half-times were performed by Bengt Ringnér, Ph.D.

\section{REFERENCES}

1. AEROSOL TECHNOLOGY COMMITTÉE, AMERICAN INDUSTRIAL HYGIENE ASSOCIATION. Guide for respirable mass sampling. Am. ind. hyg. assoc. $j$. 31 (1970) 133-137.

2. AMDUR, M. O. Rapid determination of lead in old urine samples. Arch. ind. hyg. occup. med. 7 (1953) 277-281.

3. ASKEVOLD, R. Routine analysis of porphyrines in urine. Scand. $j$. clin. lab. invest. 3 (1951) 318-319.

4. BARRY, P. S. I. A comparison of lead concentrations in human bones and in soft tissues. In: Proceedings of the international symposium on the environmental aspects of lead, Amsterdam Oct. 2-6, 1972. Commission of the European Communities, Luxembourg 1973, pp. 415-425.

5. BONSIGNORE, D., CALISSANO, P. and CARTASEGNA, C. Un semplice metodo per la determinazione della deltaaminolevulinico - deidratasi nel sangue. Comportamento dell'enzima nell'intossicazione saturnina. Med. lav. 56 (1965) 199-205.

6. CLARKSON, T. W. and KENCH, I. E. Uptake of lead by human erythrocytes in vitro. Biochem. j. 69 (1958) 432-439.

7. COMMITTEE ON BIOLOGIC EFFECTS OF ATMOSPHERIC POLLUTANTS. Lead: Airborne lead in perspectives. National Academy of Sciences, Washington, D.C. $1972,330 \mathrm{p}$.

8. DI FERRANTE, E. and BOURDEAUX, P. Metabolism and distribution of radioactive and stable lead in man. In: Proceedings of the international symposium on the environmental aspects of lead, Amsterdam Oct. 2-6 1972, Commission of the European Communities, Luxembourg 1973, pp. $357-363$.

9. DUKES, K. and FRIBERG, L. Absorption and excretion of toxic metals. Nord. hyg. tidskr. 53 (1971) 70-104.

10. GRABECKI, J., HADUCH, T. and URBANOWICZ, $H$. Die einfachen Bestimmungsmethoden der $\delta$-aminolävulinsäure im Harn. Int. Arch. Gewerbepath. 23 (1967) $226-240$.

11. GRANICK, J. L., SASSA, S., GRANICK, S., LEVERE, R. D. and KAPPAS, A. Studies in lead poisoning: II. Correlation between the ratio of activated to inactivated $\delta$-aminolevulinic acid dehydratase of whole blood and the blood lead level. Biochem. med. 8 (1.973) 149-159.

12. HAEGER-ARONSEN, B., ABDULLA, IM. and FRISTEDT, B. I. Effect of lead on $\delta$-aminolevulinic acid dehydratase activity in red blood cells. Arch. environ. health 23 (1971) 440-445.
13. HAEGER-ARONSEN, B., ABDULLA, M. and FRISTEDT, B. I. Effect of lead on $\delta$-aminolevulinic acid dehydratase activity in red blood cells: II. Regeneration of enzyme after cessation of lead exposure. Arch. environ. health 29 (1974) 150-153.

14. HERNBERG, G. S. and NIKKANEN, J. Enzyme inhibition by lead under normal urban conditions. Lancet 1 (1970) 63-64.

15. HERNBERG, S., NIKKANEN, J., MELLIN, G. and LILIUS, H. $\delta$-aminolevulinic acid dehydrase as a measure of lead exposure. Arch. environ. health 91 (1970) $140-145$.

16. HERNBERG, S., TOLA, S., NIKKANEN, J. and VALKONEN, S. Erythrocyte $\delta$ aminolevulinic acid dehydrase in new lead exposure: A longitudinal study. Arch. environ. health 25 (1972) 109-113.

17. HURSH, J. B. and MERGER, T. T. Measurement of ${ }^{212} \mathrm{~Pb}$ loss rate from human lungs. J. appl. physiol. 28 (1970) 268274.

18. MOLYNEUX, M. K. B. Use of single urine samples for the assessment of lead absorption. Br. j. ind. med. 21 (1964) 203 -209 .

19. MOORE, M. R., BEATTIE, A. D., THOMPSON, G. G. and GOLDBERG, A. Depression of $\delta$-aminolevulinic acid dehydrase activity by ethanol in man and rat. Clin. sci. 40 (1971) $81-88$.

20. PIETROWSKI, 1971. Cited by TASK GROUP ON METAL ACCUMULATION. Accumulation of toxic metals with special reference to their absorption, excretion and biological half-times. Environ. physiol. biochem. 3 (1973) 65-107.

21. PREROVSKA, I. and TEISINGER, J. Excretion of lead and its biological activity several years after termination of exposure. Br. j. ind. med. 27 (1970) 352355.

22. RABINOWITZ, M. B., WETHERILL, G. and KOPPLE, J. D. Lead metabolism in the normal human: Stable isotope studies. Science 182 (1973) 725-727.

23. RABINOWITZ, M. B., WETHERILL, G. and KOPPLE, J. D. Studies of human lead metabolism by use of stable isotope tracers. Environ. health perspectives 3 (1974) $145-153$.

24. RIMINGTON, C. and SVEINSSON, S. L. The spectrophotometric determination of uroporphyrin. Scand. j. clin. lab. invest. 2 (1950) 209-216.

25. SAKURAI, H., SUGITA, M. and TSUCHIYA, K. Biological response and subjective symptoms in low level lead exposure. Arch. environ. health 29 (1974) $157-163$.

26. SCHROEDER, H. A. and TIPTON, I. H. The human body burden of lead. Arch. environ. health 17 (1968) 965-978.

27. SCHWARTZ, S., ZIEVE, L. and WATSON, C. J. An improved method for the determination of urinary coproporphyrin and an evaluation of factors influencing the analysis. J . clin. lab. med. 27 (1951) 843-859. 
28. SCHÜTZ, A. and SKERFVING, S. Blood cell $\delta$-aminolevulinic acid dehydratase activity in humans exposed to methylmercury. Scand. j. work environ. \& health 1 (1975) $54-59$.

29. SELANDER, $S$. and CRAMÉR, $K$. Interrelationships between lead in blood, lead in urine and ALA in urine during lead work. Br. j. ind. med. 27 (1970) 28-39.

30. STERLING, T. D., KEHOE, R. A. and RUSTAGI, J. S. Mathematical analysis of lead burdens. Arch. environ. health 8 (1964) 44-51.

31. TASK GROUP ON METAL ACCUMULATION. Accumulation of toxic metals with special reference to their absorption, excretion and biological half-times. $E n_{\text {- }}$ viron. physiol. biochem. 3 (1973) 65-107.

32. TEGER-NILSSON, A.-C. Serum creatinine determination using an ion exchange resin. Scand. j. clin. lab. invest. 13 (1961) 326331.

33. TOLA, S. Erythrocyte $\delta$-aminolevulinic acid dehydratase activity after termination of lead exposure. Work-environ-health 9 (1972) 66-70.

Received for publication: 1976-03-16
34. TOLA, S. The effect of blood lead concentration, age, sex and time of exposure upon erythrocyte $\delta$-aminolevulinic acid dehydratase activity. Work-environ.-health 10 (1973) 26-35.

35. TOLA, S., HERNBERG, S., ASP, S. and NIKKANEN, J. Parameters indicative of absorption and biological effect in new lead exposure: A prospective study. $B r . j$. ind. med. 30 (1973) 134-141.

36. WALDRON, H. A. and STÖFEN, D. Subclinical lead poisoning. Academic Press, 1974. $224 \mathrm{p}$.

37. WESTERMAN, M. P., PFITZER, E., ELLIS, L. D. and JENSEN, W. N. Concentrations of lead in bone in plumbism. N. engl. j. med. 273 (1965) 1246-1249.

38. WITH, T. K. Porphyrin concentration from ultraviolet extinction: A note on the calculation. Scand. $j$. clin. lab. invest. 7 (1955) 193-194.

39. VOSTAL, J. Study of the renal excretory mechanisms of heavy metals. In: Proceedings of the $X V$ international congress on occupational health, Vienna 1966, vol. 3, pp. $61-64$. 